Food Consumption and Demographics in Japan: Implications for an Aging Population

\author{
Mauricio V. L. Bittencourt* \\ Ratapol P. Teratanavat** \\ Wen S. Chern***
}

*Mauricio V. L. Bittencourt is a graduate fellow in the Department of Agricultural, Environmental, and Development Economics at the Ohio State University. He also holds a fellowship from CAPES Foundation (Brazil) and is professor at Federal University of Parana, Brazil (UFPR). Bittencourt.1@,osu.edu

**Ratapol P Teratanavat is a graduate research associate in the Department of Agricultural, Environmental, and Development Economics at the Ohio State University. Teratanavat.1@,osu.edu

***Wen S. Chern is a professor in the Department of Agricultural, Environmental, and Development Economics at the Ohio State University. Chern.1@,osu.edu 


\title{
Food Consumption and Demographics in Japan: Implications for an Aging Population
}

\begin{abstract}
This study estimates a cross-sectional model based on the Almost Ideal Demand System (AIDS) to examine the determinants of food consumption patterns in Japan over life-cycle periods. The test of structural changes, the analysis of the effects of demographic characteristics, and the estimation of expenditure and price elasticities are conducted from a random sample of 1,281 households from a Japanese household survey in 1997. Results show that each economic or non-economic factor has a different impact on food consumption over a lifetime. Changes in consumption of some food groups can be explained by price and income effects where others can be explained by demographic characteristics. Financial constraint is not binding and residential location is likely to have little or no impact on predicting consumers' food choices at different periods of their lives. Other key factors that affect consumption pattern include family size, number of children, lifestyle and health concern.
\end{abstract}

[EconLit citations: C310, D120, D910.]

Keywords: Japan, Food Demand, Life-Cycle, AIDS, Household 


\section{Introduction}

The objectives of this study are to verify structural differences in food consumption of Japanese households at different life-cycle periods and to examine factors that may contribute to such demand changes using cross-sectional data. This study follows the underlying concept of life-cycle hypothesis ( $\mathrm{LCH})$, focusing on the intertemporal allocation of consumption over life spans. We present an analysis of Japanese demand for selected food commodities including fish, meat, milk, eggs, vegetables, and fruits. The study contains an econometric estimation of the expenditure share equations for these foods through an Almost Ideal Demand System (AIDS) specification with the presence of demographic variables. The test of structural changes, the effects of demographic characteristics, and the estimation of expenditure and price elasticities are conducted from a random sample of 1,281 households.

The assertion of $\mathrm{LCH}$ is that people smooth their consumption over time and stabilize their marginal utility of wealth with no binding liquidity constraints (Browning 1987). The time path of consumption for an individual is independent of time path of income even though an individual faces different constraints at any periods of his/her life (Deaton 1992). The main assumption under this hypothesis is that each household is maximizing his/her utility, which is a function of consumption, subject to a lifetime budget constraint. An individual will choose consumption levels in each period, not necessarily to be the same for all periods, to ensure that the marginal utility of consumption is constant or smooth over time (Attfield and Browning 1985).

Several studies tested LCH and confirmed the existence of this hypothesis in different commodities. Browning (1987) examines consumption patterns of food, alcoholic beverage, and tobacco and investigated whether LCH holds across households. The study used multi-period 
cross-sectional data with different observations to test whether consumption of alcoholic beverages and tobacco changes as family composition changes. The paper reported having children in households does not significantly decrease consumption of these goods, which supports LCH in this particular context. Blundell, Browning, and Meghir (1994) apply micro data to analyze factors influencing household allocation of goods within periods and over lifetime. Under LCH, they suggest that the relationship between marginal utility of wealth and expenditure on any individual goods depends on the shape of Engel curves, the extent of substitution between goods, the demographic composition of households, and the labor market status of the household. Controlling such factors is sufficient to eliminate the excess sensitivity of consumption growth to predictable income growth.

This study focuses on the test of structural changes in food consumption and on the examination of potential factors contributing to such changes for Japanese households. One of the most important demographic changes to have occurred in the post World War II period in Japan, is the steady increase in the average life expectancy, which has resulted in substantial ageing of the Japanese population. Therefore, the food consumption would have significant changes in the future. While most studies, dealing with $\mathrm{LCH}$, use times-series data, this study applies cross-sectional data, which enables to capture the income and price effects and the effects of various demographic characteristics on food demand. The demand model is estimated for six food commodities including fish, meat, milk, eggs, vegetables, and fruits. These food items are chosen to avoid the durability problem in the LCH analysis, as suggested by Hayashi (1985b), where some goods are not easily defined as durable or perishable. The food items chosen reflect exactly perishable features of the Japanese food consumption. 


\section{Previous Studies}

According to Hayashi (1985a), due to its forward-looking nature, the formal testing of the $\mathrm{LCH}$ is almost impossible if it is not based on a specific assumption about how expectations are formed $^{1}$. Hayashi suggested that the testing strategy should consider the relationship between current disposable income and changes in consumption. The natural approach would be to derive the household's optimal consumption rule and then to test the $\mathrm{LCH}$. In addition to the problem that it is not possible to observe the household's expectations about future income, there is not an explicit optimal consumption rule for the level of consumption, which implies there is no closedform solution for optimal consumption when future labor income is uncertain.

Although in a different context, Singh, Drost and Kumar (1978) conclude that the current income is the most important determinant of consumption expenditure. They evaluated the empirical effects of the relative income, the permanent income and the life-cycle hypothesis on aggregate consumption in Canada, India, the Netherlands, and West Germany. Therefore, this study employs current expenditure rather than permanent income in the demand system to be explained in the next sections.

Many studies tested structural changes for food consumption at different time periods and investigated determinants of such changes under the life-cycle perspective (Chalfant and Alston 1988; Cook 1993; Cortez 1994; Davis et al. 1983). Factors that contribute to structural differences of food demand in different time periods can be divided to economic and noneconomic factors. The economic factors include the responses to changes in food expenditure, household income, and prices. The response levels, which are measured by price and expenditure elasticities, may vary over time. Thus, the estimated elasticities may not be used to predict consumption patterns at different periods because the responsiveness of elderly people observed 
in the current period may not be the same as the responsiveness of today's younger people in the future period.

Non-economic factors have been the main focus by researchers to explain the changes in consumer behavior over lifetime. Such factors include family size and composition, residential location, and lifestyle. These factors can be used to predict such structural differences at different point in time because the structure of such demographic characteristics follows a similar pattern over time. Cook (1993) discusses differences in spending pattern by age and reported that spending on dairy products generally decreased with age (younger households are the one most likely to have small children) while spending on vegetables and fruits were higher in the older group. Davis et al. (1983) examine the impact of selected socioeconomic characteristics on aggregate and group food expenditure patterns using logarithmic functional form. They found that household income, family size, and Food Stamp Program participation have strong positive impacts on food expenditures.

Blundell and Walker (1984) examine the effect of variation in demographic characteristics, such as the number and ages of dependent children, on the expenditure and time allocation decisions of households. They found that young children have a significant impact on marginal budget shares. For instance, during the age between 20 and 40 years old, an individual is in the early stage of his/her career and just starts to have a family. The consumption of this group may be influenced by how many children the household has and by total household income. As people get older, they move up to higher level in their career with higher income and their children start to become independent and have their own job. Their consumption decision may be determined only by themselves without taken into account child factors. 
Kokoski (1986) investigates the effect of demographic characteristics on structural differences of food consumption and found that different demographic groups have different price and income responsiveness, using cross-sectional data. Deaton and Paxson (1998) evaluate the relationship of aging, income and health between men and women under the life-cycle perspective, where they concluded that changes in the relationship between income and health status are main factors in explaining structural changes in food consumption. Kim and Chern (1999) examine the Japanese consumption pattern of fats and oils, using translog and AIDS demand models and focusing on the impact of health risk information associated with fat and cholesterol on the demand for various fats and oils. Their results imply that lifestyle and health concerns are also factors that explain changes in consumption in different periods.

The same cross-sectional data has been used in several studies. Taniguchi and Chern (2000) examine the income and price elasticities of rice demand in Japan by applying different demand models such as Working-Lesser and linear approximated AIDS model. The results showed that the expenditure elasticity of rice is positive and close to one. Also, the own price elasticity for rice is highly elastic and rice consumption is sensitive to changes in the prices of meat and fish. Even though this study provided the descriptive statistics of food consumption and demographic composition, no emphasis was placed on differences in demand structures for different demographic groups such as income classes or age groups. They, however, pointed out that estimated expenditure and price elasticities are invariant with income levels.

Tokoyama et al. (2002) analyze overall trends in Japanese food consumption patterns. They found that elderly households have smaller expenditure elasticity than younger households, implying that older people do not change their consumption patterns as much as younger people when food expenditures increase. In addition, their study showed that expenditure and price 
elasticities become less sensitive as household size becomes larger. The study concluded that recent trends of westernization, preferences in convenience, and preferences in healthy foods have a strong explanatory power for the changing patterns of Japanese food consumption. In addition, demographic structures such as age, family size, and number of working people in households have significant impacts on food consumption.

Several studies have investigated food consumption behaviors in Japan, including Gehrt and Shim (1999), Johnson et al. (1998), Kinoshita et al. (2001), Stroppiana, Riethmuller, and Kobayashi (1998), and Watanabe et al. (1997, 1998, 1999). However, all these studies focused only on certain specific food groups. Kinoshita et al. (2001), Stroppiana, Riethmuller, and Kobayashi (1998), and Watanabe et al. $(1997,1999)$ emphasized the demand for dairy and milk products. Watanabe et al. (1998) examined the relative importance of consumer attributes on beverage consumption decisions, whereas Gehrt and Shim (1999) examined the role of fruit in Japanese snacking behavior. Demand for meat and seafood was the main focus of Johnson et al. (1998).

Our study focuses on life-cycle patterns of consumption, looking at the co-movements of consumption, expenditures and demographic variables. Since these variables are all determined jointly by the same household, looking at any pair in isolation may be misleading. The direct testing of the $\mathrm{LCH}$ is not possible due to data limitation. Since panel data is not available, where information such as asset holdings or expected future income are present, cross sectional data employed here can only be used to assess the presence of LCH through inferences from estimates of the demand system and structural change tests. The formal test of structural changes in food consumption will be conducted across age groups. This study will identify both economic and non-economic factors that may contribute to lifetime changes on food 
consumption across households. The demographic variables, as non-economic factors, are important to explain the presence of structural changes across different age groups, contributing to the verification of the LCH in the Japanese food consumption. Price and food expenditure elasticities, as economic factors, are important to gain useful information to predict the consumption behavior of the today's young people in the future under the LCH. The results of this study can help understand consumers' behavior on food consumption in different periods of their lives and factors affecting food budget allocation over lifetime, following the life-cycle hypothesis.

\section{Data and Descriptive Statistics}

The study uses data from a Japanese household survey conducted in 1997 by the Statistics Bureau, Management and Coordination Agency in Japan. This monthly survey database provides daily average information on household expenditures, prices, and quantity purchased for various food categories. The budget share is defined as the share of a particular food in total food expenditure. A sample of 1,281 observations is included in this study; only those households that report positive consumption levels on the selected food items are included in the sample ${ }^{2}$.

Household income and demographic variables such as family size, age and composition are related to the life-cycle hypothesis (Pollak and Wales, 1981). We also consider several other demographic characteristics, including the number of children in households and residential location. According to the survey, there are five income classes, in which class 1 represents lowest income group and class 5 represents highest income group ${ }^{3}$. The survey includes only those households that have two or more members, but no more than eight people. Children in 
households are divided into three groups: age less than 6 years old, between 6 and 12 years old, and older than 12 years old. The residential locations are categorized as large cities or metropolitan areas (more than 1 million people), medium size cities (between 50,000 to 1 million people), and small towns and villages (less than 50,000 people).

Data is divided into three groups based on the age of the primary householder, including age less than 41 years old, between 41 and 60 years old, and over 60 years old, in order to test the effect of social-demographic differences. The first group includes households with age less than 41 years old, representing young families with small children and lower income levels (60 percent of observations in this group are in income classes 2 and 3). The second group includes households aged between 41 and 60 years old, representing middle-age families, in which their children start to grow up and are in primary and/or high school. The income of second group is higher than the first group, in which more than 57 percent of observations are in income classes 4 and 5. In addition, people in this group are likely to be at the peak of their career, as compared to other groups. The last group represents households aged over 60 years, in which their income levels tend to decline because of the retirement and the only source of income may be from their past savings or pensions. Most households in this age group are in income classes 1, 2, and 3. Children in this group have grown up and are likely to become independent.

Table 1 shows that different age groups tend to have different daily spending patterns for food consumption. There is similarity in the consumption patterns of fish, vegetables and fruits. Japanese households increase their consumption on these foods significantly, as they become older. The consumption levels reach the highest level at the age around 50 and 60 years old and stabilize afterward. The meat consumption, however, has a different pattern, exhibiting an increasing trend until the age between 40 and 50 years old and then declines sharply once people 
become older. Milk and egg consumption patterns are relatively constant across age groups. Japanese households tend to change their budget allocation, as they become older, particularly for meat, vegetables, and fruits, while maintaining almost the same spending proportion on fish, milk, and eggs. People tend to allocate more of their food expenditure on vegetables and fruits whereas a budget share on meat declines, as people become older. The stabilized and/or smaller consumption of food at retirement age is not surprising, since the elderly faces important changes such as lower labor supply, higher mortality risk, smaller family size, and reduced health status (Browning and Crossley 2001).

Figure 1 illustrates examples of different daily food budget shares for five income classes at various age groups, allowing the examination of income effects on food consumption/spending over lifetime. Each income class has similar food spending pattern, in which Japanese tends to spend more, relative to their total food expenditures, on fish and less on meat when they are older. There is no clear distinction from the plot among different income levels on food consumption. The result may imply that the changes in consumption pattern over time do not depend on income level, followed by the existence of the life-cycle hypothesis. It is our main interest to examine further with more systematic approaches, based on the demand model in the later part, if the life-cycle hypothesis can be applicable and/or is consistent with the Japanese consumption behavior.

The descriptive statistics for these selected food items and demographic variables for each age group (table 1), provides consistent results in the average food expenditure and the food budget share. In summary, from younger to older age, households spend more on fish, vegetables, and fruits, maintain relatively constant expenditure levels on milk and eggs, and decrease their meat expenditure. Elderly people have higher food budget allocated for fish and 
fruits, constant allocation for milk, eggs, and vegetables, and smaller allocation for meat. The prices are relatively constant across age group (except for fish and meat) because they supposedly faced the same market prices.

The social demographic characteristics of Japanese households at different ages are also presented in table 1. The household income increases as household heads become older and declines after the age of 60 years old whereas the Engel coefficient, which is the ratio of food to total expenditures, suggests that older people have higher budget allocation for food. The average household income is increasing when people become older. The highest income level is reached at the age between 41 and 60 years old, which is the group of people who have been working for a long period of time. Once they are retired, the household income is likely to drop because their income sources may be limited to part-time jobs, pensions, and their savings.

Approximately 70 percent of Japanese households in all ages are located in the suburb area or medium-sized cities, while 20 percent reside in large cities, and about 10 percent live in small towns or villages. Considering the proportion of income classes across age groups, almost 60 percent of households in the age group less than 41 years old have their income in classes 2 and 3. The household income levels tend to shift upward to classes 4 and 5 when people become older and aged between 41 and 60 years old. Once they are in the retirement age, their income class move down to classes 1 and 2 .

The average number of people per household decreases, as household heads become older. Households in the younger age tend to have a larger family size than the older group. This is consistent with the reported number of children in the household. In the first age group (less than 41 years old), almost every household has at least one child aged less than 12 years. In the second age group, the age of children in the household moves up to be aged between 6 and 18 
years. The statistics implies that Japanese tend to start a family at the early age and have children during the mid 20s and 30s. Once they become older at age over 40 years old, their children start to grow up. At the retirement age, elderly people are likely to live only with their spouse whereas their children move out and live by themselves. The statistics shows that only few households in the oldest age group reported that their children (or perhaps grandchildren) aged below 18 years, if any, still stay with them.

\section{Methodology}

The underlying assumption for this study is that there is a two-stage budget decision, where the direct utility function is weakly separable and Japanese consumers allocate expenditure first to broad commodity groups and then to goods and services within each group. This assumption enables budget allocations within each group to be determined solely by withingroup relative prices and group expenditures. Therefore, it is possible to study the demand properties individually for each group of goods without lost of generality. Fish, meat, milk, eggs, vegetables and fruits are foods in the sub-group to be investigated ${ }^{4}$. The total group expenditure is derived by the total amount given by the purchases for these six food items only.

The demand model used in this study is the nonlinear Almost Ideal Demand System (AIDS) model developed by Deaton and Muellbauer (1980), which allows a flexible approximation to general preference structure. This model has been used extensively in many demand studies because it satisfies demand properties, including adding-up restriction, homogeneity, symmetry and negativity which can be imposed, Engel curves that are linear in the $\log$ of total expenditures, and exact aggregability (Asche and Wessells 1997; Lewbel 1989). 
The method of demographic translation is used to incorporate demographic variables into the demand system. It redefines the original demand system as a function of the demographic profiles of households. The model with demographic variables is still theoretical plausible, meaning that the modified model can still be derived from a well-behaved utility function (Pollak and Wales 1980). The AIDS model can be expressed as follows:

$$
w_{i}=\alpha_{i}+\sum_{j=1}^{6} \gamma_{i j} \log \left(p_{i}\right)+\beta_{i} \log \left(\frac{x}{P^{*}}\right) \quad \mathrm{i}, \mathrm{j}=1,2, \ldots, 6
$$

where $w_{i}$ is budget share for good $\mathrm{i} ; p_{i}$ is price of good $\mathrm{i} ; x$ is total food expenditure; and $\mathrm{P}^{*}$ is the AIDS price index. $\alpha_{i}, \gamma_{i j}$, and $\beta_{i}$ are parameters to be estimated. The AIDS price index ( $\mathrm{P}^{*}$ ) is a non-linear function of prices, and it can be interpreted as the log income required to attain the subsistence utility. It can be expressed as:

$$
\log P^{*}=\alpha_{0}+\sum_{i=1}^{6} \alpha_{i} \log p_{i}+\frac{1}{2} \sum_{i=1}^{6} \sum_{j=1}^{6} \gamma_{i j} \log p_{i} \log p_{j} \quad \mathrm{i}, \mathrm{j}=1,2, \ldots, 6
$$

where $\alpha_{0}$ is the $\log$ expenditure at the subsistence level when all prices are normalized at one. Demographic variables are incorporated through the following linear translation:

$$
\alpha_{i}=\alpha_{i}^{*}+\sum_{k=1}^{4} \delta_{i k} D_{k}
$$

where $D_{k}$ is demographic variable $\mathrm{k} ; \alpha_{i}^{*}$ and $\delta_{i k}$ are parameters to be estimated. 
In the AIDS model, the adding up, symmetry, and homogeneity restrictions are imposed in order to reduce the numbers of parameters to be estimated. By imposing the adding up restriction $\left(\sum_{i=1}^{6} w_{i}=1\right)$, this demand model contains five equations from fish to vegetables, by dropping the equation for fruits. The parameters for the excluded equation can be derived from the following conditions $\sum_{i=1}^{6} \alpha_{i}^{*}=1, \quad \sum_{i=1}^{6} \beta_{i}=0$, and $\sum_{i=1}^{6} \gamma_{i j}=0 \forall j$. The imposition of the symmetry restriction implies that $\gamma_{i j}=\gamma_{j i}$. As for the homogeneity restriction, $\gamma_{i j}$ is estimated for $\mathrm{j}=1,2, \ldots, 5$ and then $\gamma_{i 6}=-\left(\sum_{j=1}^{5} \gamma_{i j}\right)$ because of the homogeneity imposition $\left(\sum_{j=1}^{6} \gamma_{i j}=0\right)$ for each demand equation i. The Iterative Seemingly Unrelated Regression Model (ISUR) is applied to estimate coefficients for this AIDS model (see Appendices 1-3).

\section{Results and Discussion}

\subsection{Tests of Structural Changes}

The likelihood ratio test and the Chow test are used to investigate structural differences for a group of selected foods and each individual food commodity, respectively, across age groups, as shown in table 2. The exception is the structural differences in fruit consumption because this equation is left out whereas its parameter estimates are derived from the demand restrictions. The hypothesis to be tested is that consumption patterns across age groups are not different using the test of structural change. The rejection of the hypothesis implies that different age groups have different food consumption patterns, which can be an indicator of the presence of LCH in the Japanese food consumption. 
According to table 2, the null hypothesis of no structural changes for the whole demand system was rejected across age groups. These results imply that, considering all selected food items together, there are structural changes in consumption patterns from younger to older households, which are important results under the LCH. Considering each food item individually, the test of structural change of fish consumption shows that different consumption patterns exist between people aged less than 41 years and those who are older than 41 years old. The result is consistent with the descriptive statistics and the basic plot previously discussed. Different age groups have different consumption patterns for meat. The result follows the plots showing the increase in meat consumption from the first age group to the second group and the decrease in meat consumption from the second group to the last group.

The milk consumption of households in the younger age (less than 41 years old) and the middle age (between 41 and 60 years old) has a similar pattern. The significant difference in milk consumption is shown between people before and after retirement age (after 60 years old). People in the younger age have a different egg consumption pattern from those in the older age, but no difference is found between the second and the last age group. Egg consumption tends to be lower by older people than those in younger ages. A weak result of structural differences exists for vegetables consumption among households aged between 41 and 60 years and households aged more than 60 years. The results, in general, confirm the $\mathrm{LCH}$, since consumers at different ages seemed to maximize different utility functions when they choose among different food items to consume. 


\subsection{Effects of Demographic Variables}

There is no strong evidence showing significant effects of income classes on consumption pattern for the most part of income class coefficients in all system results, which can be considered as a weak response for the LCH. Most of parameter estimates are not statistically significant at the 5 percent level, as shown in table 3. People in the same age group with different income levels tend to have similar consumption patterns for all selected foods. This can imply that income constraint is not a key factor for making their available budget allocation among these food items. If this constraint is binding or plays a main role in the $\mathrm{LCH}$, people in different income classes should have different consumption patterns. However, stronger evidence is needed to support this hypothesis. Again, this result is consistent with the simple plot of different food consumption across income classes presented earlier. Browning and Crossley (2001) found that absence of high correlation between consumption and income is not a sign that the LCH does not hold. It can be just a special case of LCH, keeping in mind that smoothing consumption does not mean constant consumption.

Considering the regression results for fish, the estimated coefficients of family size change from positive to negative when households become older. Parameter estimates of residential location are significant only for the oldest age group (those over 60 years old). Households living in large cities tend to consume less fish than those living in small towns or villages. Number of children in household is likely to have a negative impact on consumption levels. Surprisingly, households with children are likely to consume less fish. The number of children under age of 6 years old has significant influence on fish consumption in the young households, while the number of children in school ages is a significant factor to those households in the middle age (between 41 and 60 years old). Number of children does not have 
any influence on fish consumption of households in the oldest age group, which can be explained by the fact that people in this age group live by themselves with no children in the family. Thus, their consumption will depend solely on their own choices and needs.

With respect to meat demand, households with more people tend to consume more in the older age groups while the household size has little or no effect in the youngest age group. Residential location seems to have no effect on meat and milk consumption across age groups. However, the number of children tends to have a significant effect on both foods. It seems reasonable that consumption of meat and milk is high for people with children or teenagers. Once children become more independent and live on their own, as in the case of older households (more than 60 years old), the consumption of meat and milk decreases.

Family size and residential location are the main demographic variables to explain egg consumption for all three age groups, with positive and significant coefficients in all estimates for family size, and negative and significant coefficients for the large city variable for the first two age groups. For vegetables demand, once again family size and location are the only important demographic variables to explain their consumption for the younger (between 41 and 60 years old) and older (more than 60 years old) households. The results show that demographic characteristics such as household composition do not have strong effects on consumption pattern across age groups for eggs and vegetables. The structural differences in these food items may be explained by the fact that people in older ages are more concerned about their health and thus decrease their egg consumption and increase their fruit and vegetable consumption.

It is shown that differences through the life cycle obtained from the structural change tests can be explained by the results from demographic variables that we discussed in this section. Non-economic factors such as location, household size and household composition are 
accounted partially to explain the pattern of consumption compatible with the LCH. The joint effect of consumer's preference and health concerns may also be responsible for such differences; this effect, nevertheless, cannot be tested using the available data.

\subsection{Effects of Prices and Food Expenditure}

The effects of expenditure and prices on food demand, as measured by expenditure and price elasticities, may contribute to changing patterns of food consumption across age groups. Information contained in these elasticity estimates may be used to predict consumers' behavior over time with panel data. With the availability of only cross sectional data, the usefulness of such information is limited to the present analysis under the LCH. However, this study attempts to predict the future behavior of consumers using the present elasticity results with some caution.

The expenditure elasticities of selected foods in this study show that, on average, fish, fruits, and, in some degree, meat, tend to be expenditure elastic goods for all age groups analyzed (table 4$)^{5}$. Others are more expenditure inelastic (necessity) goods, where eggs have the smallest elasticity, mainly for the oldest age group. An increase in income is likely to have a more significant impact on fish, fruits, and vegetables than on milk and egg consumption. As people become older, more food expenditure will be allocated for fish, vegetables, and fruits and less for meat, milk, and eggs.

The Hicksian compensated price elasticities can give the substitutability effects among all food items, and they show that all selected food items are essential for the Japanese consumers, with low own-price elasticity (table 5). An increase in price by 1 percent of these food items will decrease the consumption by 0.1 to 0.6 percent. The cross-price elasticities show that, for all age groups, fish and meat are substitutes. Fish seems to be a substitute for all foods, except for milk 
in the first and last age groups (less than 41 and over 60 years old). In general, meat is shown to be a complement food for milk and eggs for the first two age groups. Vegetables seem to be substitutes for all foods across all age groups. The results are very similar to those found by Taniguchi and Chern (2000).

It is noted (table 5) that there are some distinct patterns of price responsiveness across age groups. In general, the own-price elasticities tend to be more sensitive as people become older, except for fish, eggs, and fruits. The substitution elasticities also tended to be higher as consumers become older, especially for fish and meat. For eggs and vegetables, the substitution elasticities decreased across age groups and for milk and fruits there were some elasticities that increased and other decreased across age groups. These results emphasize our previous assertions that different utility functions are used by consumers in each age group, which seems to be a reasonable result from $\mathrm{LCH}$. With cross-section data in this study, nonetheless, a conclusion cannot be drawn if the future responsiveness to changes in food expenditure and prices for households will be the same as the current responsiveness estimated in our analysis. It may not be reasonable to assume that, 20 years from now, households in the first age group (less than 41 years old) will follow the current expenditure and price responsiveness of those households in the second age group (between 41 and 60 years old). Our belief is that, in the future, different age groups will behave differently among them because they may pose distinct utility functions, preferences, and opportunity sets due to the emerging technology and information sets (Browning and Crossley 2001). It is called heterogeneity, and Browning, Hansen and Heckman (1999) is one of few studies that dealt with this issue under LCH. 


\section{Conclusions}

Cross-sectional data can be used to provide inferences on food consumption under the life-cycle hypothesis. Each economic or non-economic factor has a different impact on food consumption over a lifetime. Changes in Japanese consumption of some food groups can be explained by price and income effects where others can be explained by demographic characteristics. Financial constraint is not binding and residential location is likely to have no/little impact to predict how people choose their food at different period of their lives. Although economic factors such as prices and expenditure are also shown to have significant impacts on food choices, it cannot be simply assumed that such patterns of price and expenditure responsiveness will be carried over to next generations. It is difficult to generalize the behavioral results found for people aged more than 41 or more than 60 years to be the same that it will be for the current people aged less than 41 because the social and economic environment, preferences and health concerns change over time.

As Japan's population is rapidly ageing, we may expect, based on the results of this study, that the country would consume more of fish, fruits, and vegetables, but less of meats and eggs. It is also suggested that there are important differences in consumption patterns across different life-cycle periods, stressing how different consumption behaviors can be across distinct age groups. Government authorities, policy makers, and the food industry should take into account in their actions all important results found in this study for the elder Japanese households, since the average age is becoming higher in Japan in recent times, it is very likely that the consumer behavior of elder households will be a very relevant information for economic agents in the future. 
The factors that affect consumption pattern over time and can be used to predict how people consume at different life cycle periods are family size and household composition. These factors are shown to have influence on structural differences in food consumption across age groups, following structural shifts of certain demographic characteristics. Number of children has significant effects on consumption of some food groups such as fish, meat, and milk at different ages. There is no strong evidence, however, about the effects of these demographic variables on eggs, vegetables, and fruits consumption. Income classes are not significant factors for explaining the changes in food consumption pattern over a lifetime. However, residential location can affect fish, meat, eggs, and vegetables consumption at different ages. Other variables such as education level and fertility could also be important to capture structural changes across age groups in future studies. The results shown are coherent to what would be expected from $\mathrm{LCH}$.

Changes in food consumption across age groups may also be explained by different lifestyle and health concerns. Older people may be more concerned about their health and thus, more selective on dietary intakes by consuming more of healthy foods with high vitamin and minerals and less cholesterol, such as fish, vegetables, and fruits while eating less meat products. Even though this factor may contribute to such structural differences of food consumption at different ages, this study does not have enough information to examine such impacts.

As pointed out by Watts (1958), cross-section data does not allow the verification of the real relationship across different "generations" given by three different age groups ${ }^{6}$. It is so because the experience of a generation is, at least partially, unique, since it differs from that of other generations in events and situations, and also differs in terms of the timing of these events relative to the life cycle. The consequence of the generalization from the use of cross-section 
data depends on a ceteris paribus assumption about the experience of different generations or age groups.

This study represents only an attempt to investigate the Japanese food consumption under LCH. The most interesting finding is that the food consumption pattern in Japan can be explained by economic (price, income) and demographic factors (household composition, family size, residential location) under the life-cycle hypothesis. As the households become older, they change their food consumption pattern influenced by economic, demographic, and other factors such as lifestyle and health. 


\section{Endnotes}

1. Hall (1978) tested the permanent income hypothesis on U.S. assuming rational expectations.

2. There was a relatively small percentage of household reported no spending on these food items during the survey period; $2.6 \%$ (fish), 1.9\% (meat), $7.6 \%$ (milk), 5.3\% (eggs), $0.2 \%$ (vegetables), and $6.1 \%$ (fruits). These observations are excluded from the study in order to avoid zero truncated problems. The AIDS model with all observations (available upon request) is very similar to the model without these observations shown in the tables.

3. According to the survey, household income is classified into five different levels. Class 1 represents households with annual income less than 4,020,000 Yen; Class 2 is between 4,020,000 and 5,680,000 Yen; Class 3 is between 5,680,000 and 7,450,000 Yen; Class 4 is between 7,450,000 and 9,900,000 Yen; and Class 5 is between 9,900,000 Yen and higher.

4. To avoid this problem, Deaton (1974) included a constant in the models to represent the other important commodity groups that were not specified in the models. In this case, Deaton had many different groups of goods that were separated to be estimated under different demand system specifications, which it is not the case in this study because this is only a six-good analysis.

5. Taniguchi and Chern (2000) and Chern et al. (2003) obtained similar results for the same food items.

6. Weil (1994) also emphasizes the interrelationships among generations of households. 


\section{References}

Asche, F., \& Wessells, C.R. (1997). On Price Indices in the Almost Ideal Demand System. American Journal of Agricultural Economics, 79 (November), 1182-85.

Attfield, C. L., \& Browning, M. (1985). A Differential Demand System, Rational Expectations and the Life-cycle Hypothesis. Econometrica, 53 (January), 31-48.

Blundell, R., Browning, M., \& Meghir, C. (1994). Consumer Demand and the Life-Cycle Allocation of Household Expenditures. The Review of Economic Studies, 61 (January), 5780.

Blundell, R., \& Walker, I. (1984). A Household Production Specification of Demographic Variables in Demand Analysis. The Economic Journal, 94 (Supplement), 59-68.

Browning, M. (1987). Eating, Drinking, and Testing the Lifecycle Hypothesis. The Quarterly Journal of Economics, 102 (May), 329-46.

Browning, M., \& Crossley, T. (2001). The Life-Cycle Model of Consumption and Saving. Journal of Economic Perspectives, 15 (Summer), 3-22.

Browning, M., Hansen, L., \& Heckman, J. (1999). Micro Data and General Equilibrium Models. In J. Taylor, \& M. Woodford (Eds.), Handbook of Macroeconomics, Vol. IA, New York, NY: Elsevier Science.

Chalfant, J.A., \& Alston, J.M. (1988). Accounting for Changes in Tastes. Journal of Political Economy, 96 (April), 391-408.

Chern, W.S., Ishibashi, K., Taniguchi, K., \& Tokoyama, Y. (2003). Analysis of the Food Consumption of Japanese Households. Food and Agriculture Organization of the United Nations (FAO), Economic and Social Development Paper, No. 152. Rome, Italy. 
Cook, A.K. (1994). Changes in Japanese Food Consumption. In A.D. O'Rourke (Eds.), Understanding the Japanese Food and Agrimarket: A Multifaceted Opportunity, New York, NY: Food Products Press.

Cortez, R.A. (1994). Taste Changes in the Demand for Food by Demographic Groups in the United States: A Non-parametric Empirical Analysis. Ph.D. Dissertation. University of Minnesota.

Davis, C.G., Moussie, M., Dinning, J.S., \& Christakis, G.J. (1983). Socioeconomic Determinants of Food Expenditure Patterns among Racially Different Low- Income Households: An Empirical Analysis. Western Journal of Agricultural Economics, 8 (December), 183-196.

Deaton, A.S. (1992). Understanding Consumption. New York, NY: Clarendon Press.

Deaton, A.S., \& Muellbauer, J. (1980). An almost Ideal Demand System. The American Economic Review, 70 (June), 312-26.

Deaton, A.S., \& Paxson, C. (1998). Aging and Inequality in Income and Health. The American Economic Review, 88 (May), 248-53.

Gehrt, K.C., \& Shim, S. (1999). The Magnitude and Nature of Situational Influence on Japanese Snacking: The Role of Fruit. Agribusiness, 15 (1), 119-136.

Hall, R.E. (1978). Stochastic Implications of the Life-Cycle Permanent Income Hypothesis: Theory and Evidence. Journal of Political Economy, 86 (December), 971-87.

Hayashi, F. (1985a). The Effect of Liquidity Constraints on Consumption: A Cross-Sectional Analysis. The Quarterly Journal of Economics, 100 (February), 183-206.

Hayashi, F. (1985b). The Permanent-Income Hypothesis and Consumption Durability: Analysis Based on Japanese Panel Data. The Quarterly Journal of Economics, 100 (November), 10831113. 
Johnson, A., Durham, C., \& Wessells, C. (1998). Seasonality in Japanese Household Demand for Meat and Seafood. Agribusiness, 14 (4), 337-51.

Kim S.R., \& Chern, W.S. (1999). Alternative Measures of Health Information and Demand for Fats and Oils in Japan. The Journal of Consumer Affairs, 33 (Summer), 92-109.

Kinoshita, J., Suzuki, N., Kawamura, T., Watanabe, Y., \& Kaiser, H. (2001). Estimating Own and Cross Brand Price Elasticities, and Price-Cost Margin Ratios using Store-Level Daily Scanner Data. Agribusiness, 17 (4), 515-25.

Kokoski, M.F. (1986). An Empirical Analysis of Intertemporal and Demographic Variations in Consumer Preferences. American Journal of Agricultural Economics, 68 (November), 894907.

Lewbel, A. (1989). Nesting the AIDS and Translog Demand Systems. International Economic Review, 30 (May), 349-356.

Pollak, R.A., \& Wales, T.J. (1980). Comparison of the Quadratic Expenditure System and Translog Demand System with Alternative Specifications of Demographic Effects. Econometrica, 48 (April), 595-612.

Pollak, R.A., \& Wales, T.J. (1981). Demographic Variables in Demand Analysis. Econometrica, 49 (November), 1533-1551.

Singh, B., Drost, H., \& Kumar, R.C. (1978). An Empirical Evaluation of the Relative, the Permanent Income, and the Life-Cycle Hypotheses. Economic Development and Cultural Change, 26 (January), 281-305.

Stroppiana, R., Riethmuller, P., \& Kobayashi, K. (1998). Regional Differences in the Japanese Diet: the Case of Drinking Milk. Economic Analysis and Policy, 28 (1), 85-102. 
Taniguchi, K., \& Chern, W.S. (2000). Income Elasticity of Rice Demand in Japan and its Implications: Cross Sectional Data Analysis. Paper presented at the 2000 Annual American Agricultural Economics Association, Tampa, FL, July 30 - August 2.

Tokoyama, Y., Takagi, S., Ishibashi, K., \& Chern, W.S. (2002). Recent Food Consumption Pattern of Japanese Households: Driving Forces behind Westernization. Paper presented at the 2002 Annual Meeting American Agricultural Economics Association, Long Beach, CA, July 28-31.

Wattanabe, Y., Suzuki, N., \& Kaiser, H. (1997). Identifying Consumer Characteristics Associated with Japanese Preferences Toward Milk Products. Agribusiness, 13 (4), 357-63.

Wattanabe, Y., Suzuki, N., \& Kaiser, H. (1998). Factors Affecting Consumer's Choice of Beverages in Japan. Agribusiness, 14 (2), 147-56.

Wattanabe, Y., Suzuki, N., \& Kaiser, H. (1999). Predicting Japanese Dairy Consumption Behavior Using Qualitative Survey Data. Agribusiness, 15 (1), 71-79.

Watts, H. (1958). Long-Run Income Expectations and Consumer Savings. In T. Dernburg, et al. (Eds.), Studies in Household Economic Behavior, New Haven, CT: Yale University Press. Weil, D. (1994). The Saving of the Elderly in Micro and Macro Data. The Quarterly Journal of Economics, 109 (February), 55-81. 
Table 1: Sample means for different food items and demographic variables

\begin{tabular}{|c|c|c|c|c|}
\hline & Variables & $\begin{array}{l}\text { Age Less } \\
\text { Than } 41 \text { years } \\
(\mathrm{N}=317)\end{array}$ & $\begin{array}{c}\text { Age Between } \\
41 \text { and } 60 \\
\text { years } \\
(\mathrm{N}=620)\end{array}$ & $\begin{array}{c}\text { Age More } \\
\text { Than } 60 \text { years } \\
(\mathrm{N}=344)\end{array}$ \\
\hline \multirow{6}{*}{$\begin{array}{l}\text { Daily Food } \\
\text { Expenditure per } \\
\text { Household (Yen) }\end{array}$} & Fish & 126.71 & 235.58 & 262.24 \\
\hline & Meat & 170.13 & 243.58 & 158.25 \\
\hline & Milk & 62.32 & 76.55 & 74.89 \\
\hline & Eggs & 26.94 & 31.70 & 24.14 \\
\hline & Vegetables & 153.19 & 230.56 & 230.13 \\
\hline & Fruits & 73.88 & 128.32 & 173.33 \\
\hline \multirow{6}{*}{$\begin{array}{l}\text { Price }(\text { Yen/g; except } \\
\text { for milk, Yen/ } 100 \mathrm{ml})\end{array}$} & Fish & 1.77 & 1.85 & 1.98 \\
\hline & Meat & 1.53 & 1.78 & 1.96 \\
\hline & Milk & 0.20 & 0.21 & 0.23 \\
\hline & Eggs & 0.28 & 0.28 & 0.29 \\
\hline & Vegetables & 0.41 & 0.42 & 0.42 \\
\hline & Fruits & 0.50 & 0.49 & 0.58 \\
\hline \multirow{6}{*}{ Budget Share } & Fish & $19.21 \%$ & $23.83 \%$ & $26.73 \%$ \\
\hline & Meat & $27.51 \%$ & $25.00 \%$ & $17.52 \%$ \\
\hline & Milk & $10.79 \%$ & $8.81 \%$ & $8.92 \%$ \\
\hline & Eggs & $4.82 \%$ & $3.74 \%$ & $2.97 \%$ \\
\hline & Vegetables & $25.94 \%$ & $25.07 \%$ & $25.89 \%$ \\
\hline & Fruits & $11.71 \%$ & $13.52 \%$ & $17.94 \%$ \\
\hline \multicolumn{5}{|c|}{ Demographic Characteristics } \\
\hline \multirow{2}{*}{\multicolumn{2}{|c|}{$\begin{array}{l}\text { Household Annual Income (Million Yen) } \\
\text { Age of Householder }\end{array}$}} & 6.49 & 8.56 & 6.08 \\
\hline & & 34.53 & 50.22 & 68.49 \\
\hline Income Class 1 & $\begin{array}{l}\text { Annual Income less than 4,020,000 } \\
\text { Yen }\end{array}$ & $12.93 \%$ & $11.13 \%$ & $34.59 \%$ \\
\hline Income Class 2 & $\begin{array}{l}\text { Between 4,020,000 and 5,680,000 } \\
\text { Yen }\end{array}$ & $30.59 \%$ & $12.10 \%$ & $25.00 \%$ \\
\hline Income Class 3 & $\begin{array}{l}\text { Between 5,680,000 and 7,450,000 } \\
\text { Yen }\end{array}$ & $28.39 \%$ & $19.52 \%$ & $17.44 \%$ \\
\hline Income Class 4 & $\begin{array}{l}\text { Between 7,450,000 and 9,900,000 } \\
\text { Yen }\end{array}$ & $19.55 \%$ & $27.42 \%$ & $9.88 \%$ \\
\hline Income Class 5 & Higher than $9,900,000$ Yen & $8.52 \%$ & $29.83 \%$ & $13.08 \%$ \\
\hline Large City & Population more than 1 million & $17.03 \%$ & $18.39 \%$ & $18.31 \%$ \\
\hline Medium Sized City & $\begin{array}{l}\text { Population between } 50,000 \text { and } 1 \\
\text { million }\end{array}$ & $70.97 \%$ & $66.45 \%$ & $67.15 \%$ \\
\hline $\begin{array}{l}\text { Small Town and } \\
\text { Villages }\end{array}$ & Population less than 50,000 & $11.98 \%$ & $15.16 \%$ & $14.53 \%$ \\
\hline Household Sizes & Numbers of people in a household & 3.77 & 3.65 & 2.56 \\
\hline Children under 6 & $\begin{array}{l}\text { Numbers of children aged less than } \\
6 \text { years in a household }\end{array}$ & 0.81 & 0.10 & 0.03 \\
\hline Children between 6-12 & $\begin{array}{l}\text { Numbers of children aged between } \\
6 \text { and } 12 \text { years in a household }\end{array}$ & 0.72 & 0.36 & 0.04 \\
\hline $\begin{array}{l}\text { Children between } 12- \\
18\end{array}$ & $\begin{array}{l}\text { Numbers of children aged between } \\
12 \text { and } 18 \text { years in a household }\end{array}$ & 0.12 & 0.52 & 0.03 \\
\hline
\end{tabular}


Table 2: Statistics for structural differences across age groups

\begin{tabular}{|c|c|c|c|}
\hline & $\begin{array}{l}\text { Age Less Than } 41 \text { vs. } \\
\text { Age Between } 41 \text { and } 60\end{array}$ & $\begin{array}{c}\text { Age Less Than } 41 \text { vs. } \\
\text { Age More Than } 60\end{array}$ & $\begin{array}{c}\text { Age Between } 41 \text { and } 60 \\
\text { vs. } \\
\text { Age More Than } 60 \\
\end{array}$ \\
\hline \multicolumn{4}{|c|}{ Likelihood Ratio Test ${ }^{a}$} \\
\hline $\begin{array}{l}\text { The group of five } \\
\text { food commodities }\end{array}$ & $4037.6^{*}$ & $209.8^{*}$ & $3,827.8^{*}$ \\
\hline \multicolumn{4}{|l|}{ Chow Test ${ }^{b}$} \\
\hline Fish & $1.827^{*}$ & 1.508 & 0.743 \\
\hline Meat & $2.814^{*}$ & $6.237^{*}$ & $3.401 *$ \\
\hline Milk & 1.090 & $1.599^{*}$ & $2.085^{*}$ \\
\hline Eggs & $1.873^{*}$ & $1.847^{*}$ & 0.868 \\
\hline Vegetables & 1.115 & 0.976 & $2.246^{*}$ \\
\hline
\end{tabular}

Note: $*$ indicates that the hypothesis that there is no structural change between different age groups is rejected at $95 \%$ confidence.

${ }^{\text {a }}$ Critical Chi-Squared value is $28.87(\mathrm{df}=18,5 \%)$

${ }^{\mathrm{b}}$ Critical F-Value is $1.57(\mathrm{df}=18,>300)$. 
Table 3: Parameter estimates of demographic characteristics for six food commodities

\begin{tabular}{|c|c|c|c|c|c|c|c|c|c|}
\hline \multirow[b]{2}{*}{$\begin{array}{l}\text { Demographic } \\
\text { Characteristics }\end{array}$} & \multicolumn{3}{|c|}{ Fish } & \multicolumn{3}{|c|}{ Meat } & \multicolumn{3}{|c|}{ Milk } \\
\hline & $\begin{array}{c}\text { Age } \\
\text { Less } \\
\text { Than } 41\end{array}$ & $\begin{array}{c}\text { Age } \\
\text { Between } \\
41 \text { and } \\
60\end{array}$ & $\begin{array}{c}\text { Age } \\
\text { Over } 60\end{array}$ & $\begin{array}{c}\text { Age } \\
\text { Less } \\
\text { Than } 41\end{array}$ & $\begin{array}{c}\text { Age } \\
\text { Between } \\
41 \text { and } \\
60\end{array}$ & $\begin{array}{c}\text { Age } \\
\text { Over } 60\end{array}$ & $\begin{array}{c}\text { Age } \\
\text { Less } \\
\text { Than } 41\end{array}$ & $\begin{array}{c}\text { Age } \\
\text { Between } \\
41 \text { and } \\
60\end{array}$ & $\begin{array}{c}\text { Age } \\
\text { Over } 60\end{array}$ \\
\hline Income Class 2 & -0.013 & $0.037 *$ & -0.022 & -0.002 & 0.003 & -0.003 & 0.006 & $-0.022 *$ & 0.005 \\
\hline Income Class 3 & -0.013 & 0.013 & -0.024 & -0.011 & 0.007 & -0.005 & 0.009 & -0.002 & $0.025^{*}$ \\
\hline Income Class 4 & -0.010 & 0.018 & -0.014 & $-0.067 *$ & -0.018 & 0.007 & $0.036^{*}$ & 0.000 & 0.021 \\
\hline Income Class 5 & $-0.078 *$ & 0.008 & -0.008 & -0.029 & -0.020 & -0.007 & $0.030^{*}$ & 0.012 & $0.029 *$ \\
\hline Family size & $0.022 *$ & -0.008 & $-0.019 *$ & -0.010 & $0.010^{*}$ & $0.039^{*}$ & -0.009 & 0.005 & -0.006 \\
\hline Large City & -0.025 & -0.021 & $-0.059 *$ & -0.013 & 0.000 & $-0.040 *$ & 0.018 & 0.003 & -0.015 \\
\hline Medium Sized City & -0.005 & -0.016 & -0.030 & -0.033 & -0.004 & -0.021 & 0.018 & 0.011 & $-0.021 *$ \\
\hline Children under 6 & $-0.030 *$ & -0.006 & 0.007 & -0.005 & 0.011 & $-0.063 *$ & $0.032 *$ & -0.001 & $0.044^{*}$ \\
\hline $\begin{array}{l}\text { Children between 6- } \\
12 \\
\text { Children between }\end{array}$ & -0.015 & $-0.023^{*}$ & -0.008 & -0.003 & $0.011^{*}$ & $-0.070 *$ & 0.013 & $0.017^{*}$ & $0.036^{*}$ \\
\hline $12-18$ & -0.025 & $-0.019 *$ & -0.012 & $0.054 *$ & $0.034 *$ & $0.068^{*}$ & 0.013 & $0.008^{*}$ & -0.001 \\
\hline
\end{tabular}

\begin{tabular}{|c|c|c|c|c|c|c|c|c|c|}
\hline \multirow[b]{2}{*}{$\begin{array}{l}\text { Demographic } \\
\text { Characteristics }\end{array}$} & \multicolumn{3}{|c|}{ Eggs } & \multicolumn{3}{|c|}{ Vegetables } & \multicolumn{3}{|c|}{ Fruits } \\
\hline & $\begin{array}{c}\text { Age } \\
\text { Less } \\
\text { Than } 41\end{array}$ & $\begin{array}{c}\text { Age } \\
\text { Between } \\
41 \text { and } \\
60\end{array}$ & $\begin{array}{c}\text { Age } \\
\text { Over } 60\end{array}$ & $\begin{array}{c}\text { Age } \\
\text { Less } \\
\text { Than } 41\end{array}$ & $\begin{array}{c}\text { Age } \\
\text { Between } \\
41 \text { and } \\
60\end{array}$ & $\begin{array}{c}\text { Age } \\
\text { Over } 60\end{array}$ & $\begin{array}{c}\text { Age } \\
\text { Less } \\
\text { Than } 41\end{array}$ & $\begin{array}{c}\text { Age } \\
\text { Between } \\
41 \text { and } \\
60\end{array}$ & $\begin{array}{c}\text { Age } \\
\text { Over } 60\end{array}$ \\
\hline Income Class 2 & -0.002 & 0.003 & -0.002 & 0.005 & -0.006 & -0.016 & 0.007 & -0.015 & 0.038 \\
\hline Income Class 3 & 0.000 & 0.000 & -0.001 & 0.007 & -0.008 & -0.017 & 0.008 & -0.010 & 0.023 \\
\hline Income Class 4 & -0.008 & 0.000 & -0.002 & 0.006 & 0.012 & -0.027 & 0.043 & -0.012 & 0.014 \\
\hline Income Class 5 & 0.005 & -0.002 & 0.002 & 0.021 & 0.004 & -0.029 & 0.050 & -0.002 & 0.012 \\
\hline Family size & $0.008 *$ & $0.003 *$ & $0.006^{*}$ & $-0.012 *$ & -0.002 & 0.007 & 0.010 & -0.008 & -0.027 \\
\hline Large City & $-0.011^{*}$ & $-0.005^{*}$ & 0.003 & $0.042 *$ & 0.008 & $0.080^{*}$ & -0.012 & 0.015 & 0.031 \\
\hline Medium Sized City & -0.007 & -0.004 & -0.003 & 0.048 & -0.002 & $0.076^{*}$ & -0.022 & -0.015 & 0.000 \\
\hline Children under 6 & -0.004 & -0.003 & -0.009 & 0.003 & 0.016 & -0.004 & 0.003 & -0.017 & 0.025 \\
\hline $\begin{array}{l}\text { Children between 6- } \\
12 \\
\text { Children between }\end{array}$ & 0.000 & 0.001 & $-0.011 *$ & 0.005 & -0.007 & 0.002 & -0.002 & 0.000 & 0.052 \\
\hline $12-18$ & -0.006 & $0.003 *$ & 0.000 & -0.005 & -0.008 & -0.011 & -0.032 & -0.017 & -0.043 \\
\hline
\end{tabular}

Note: * indicates statistically significant coefficient at $90 \%$ confidence. 
Table 4: Expenditure elasticity for different age groups ${ }^{\text {a }}$

\begin{tabular}{lccc}
\hline \multicolumn{1}{c}{ Food Item } & Age Less Than 41 & Age Between 41 and 60 & Age More Than 60 \\
\hline Fish & 1.17 & 1.21 & 1.22 \\
Meat & 1.07 & 1.05 & 0.83 \\
Milk & 0.76 & 0.63 & 0.49 \\
Eggs & 0.54 & 0.47 & 0.39 \\
Vegetables & 0.91 & 0.92 & 1.01 \\
Fruits & 1.13 & 1.04 & 1.15 \\
\hline
\end{tabular}

${ }^{a}$ Expenditure Elasticity is estimated by the following formula: $\quad e_{i}=1+\frac{\beta_{i}}{w_{i}}$ 
Table 5: Hicksian compensated price elasticity for different age group ${ }^{\text {a }}$

\begin{tabular}{lcccccc}
\hline & Price-Fish & Price-Meat & Price-Milk & Price-Eggs & Price-Vegt. & Price-Fruits \\
\hline Age Less than & 41 & & & & & \\
Fish & -0.443 & 0.238 & -0.048 & 0.040 & 0.157 & 0.057 \\
Meat & 0.166 & -0.302 & -0.024 & -0.029 & 0.107 & 0.083 \\
Milk & -0.085 & -0.062 & -0.162 & -0.015 & 0.247 & 0.778 \\
Eggs & 0.159 & -0.168 & -0.034 & -0.381 & 0.393 & 0.031 \\
Vegetables & 0.116 & 0.114 & 0.103 & 0.073 & -0.515 & 0.109 \\
Fruits & 0.094 & 0.194 & 0.072 & 0.013 & 0.241 & -0.613 \\
\hline Age Between & 41 and 60 & & & & & \\
Fish & -0.418 & 0.150 & 0.013 & 0.018 & 0.177 & 0.060 \\
Meat & 0.143 & -0.309 & -0.030 & 0.014 & 0.038 & 0.145 \\
Milk & 0.034 & -0.086 & -0.108 & 0.016 & 0.112 & 0.031 \\
Eggs & 0.115 & 0.093 & -0.038 & -0.439 & 0.229 & -0.037 \\
Vegetables & 0.168 & 0.038 & 0.040 & 0.034 & -0.336 & 0.056 \\
Fruits & 0.106 & 0.268 & 0.020 & -0.010 & 0.105 & -0.489 \\
\hline Age over 60 & & & & & & \\
Fish & -0.334 & 0.096 & -0.033 & 0.013 & 0.145 & 0.113 \\
Meat & 0.146 & -0.405 & 0.049 & 0.007 & 0.222 & -0.019 \\
Milk & -0.099 & 0.097 & -0.206 & 0.037 & 0.242 & -0.071 \\
Eggs & 0.115 & 0.041 & 0.120 & -0.358 & 0.153 & -0.063 \\
Vegetables & 0.150 & 0.150 & 0.084 & 0.018 & -0.560 & 0.159 \\
Fruits & 0.168 & -0.019 & -0.035 & -0.010 & 0.229 & -0.333 \\
\hline & & & & & & \\
\hline
\end{tabular}

${ }^{\text {a }}$ Hicksian compensated elasticities are expressed as: $\quad s_{i j}=e_{i j}+\left(\bar{w}_{j} * e_{i}\right)$

The corresponding elasticities can be estimated by the following formula

$$
\begin{aligned}
& e_{i i}=\frac{\gamma_{i j}-\beta_{i}\left(\bar{w}_{j}-\beta_{j} \ln (X / P)\right)}{\bar{w}_{i}}-\delta_{i j} \\
& \text { where } \delta_{i j}= \begin{cases}1 & \text { if } i=j \\
0 & \text { Otherwise }\end{cases}
\end{aligned}
$$


Figure 1: Food consumption (budget share) by income class over life time, 1997

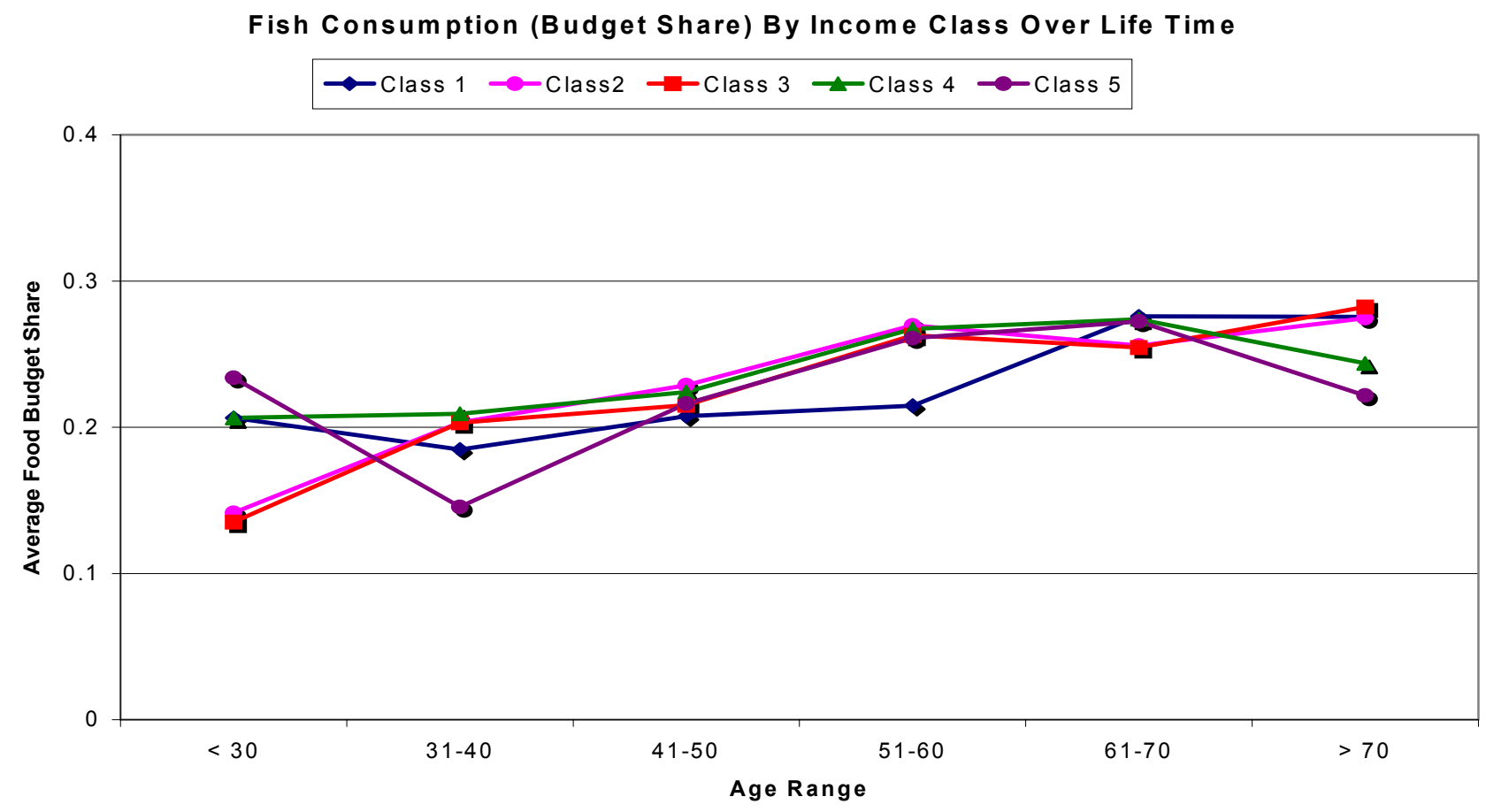

Meat Consumption (Budget Share) By Income Class Over Life Time

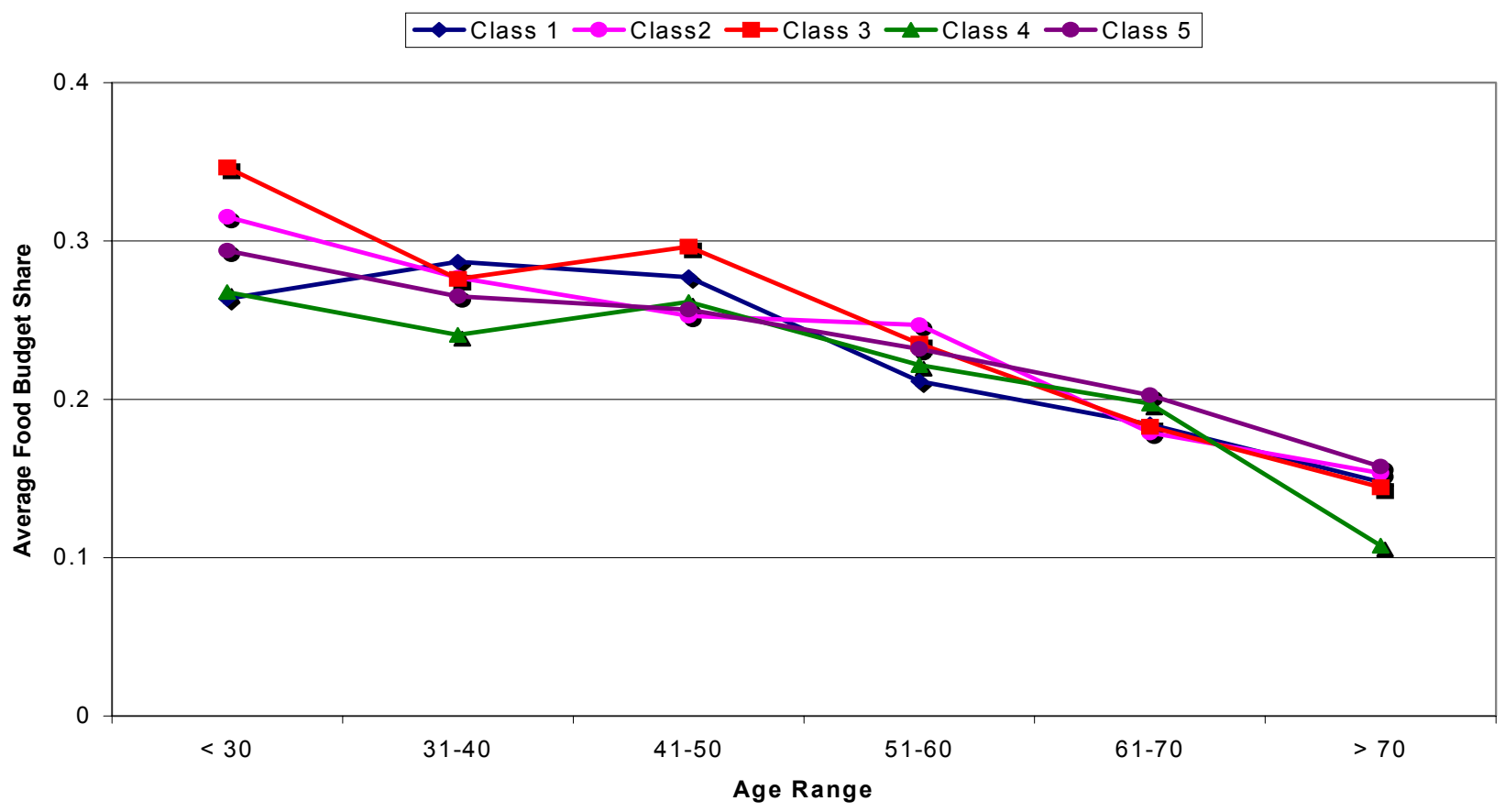


Appendix 1: Parameter estimates of the AIDS model for age group less than $41^{\text {a }}$

\begin{tabular}{|c|c|c|c|c|c|c|}
\hline & Fish & Meat & Milk & Eggs & Vegetables & Fruits \\
\hline Alpha & $\begin{array}{c}-0.1571 * \\
(0.084)\end{array}$ & $\begin{array}{l}0.0458 \\
(0.094)\end{array}$ & $\begin{array}{c}0.3887 * \\
(0.063)\end{array}$ & $\begin{array}{c}0.2112 * \\
(0.024)\end{array}$ & $\begin{array}{c}0.4745^{*} \\
(0.073)\end{array}$ & 0.0368 \\
\hline Beta & $\begin{array}{c}0.0332 * \\
(0.013)\end{array}$ & $\begin{array}{l}0.0203 \\
(0.014)\end{array}$ & $\begin{array}{c}-0.0258 * \\
(0.008)\end{array}$ & $\begin{array}{c}-0.0218^{*} \\
(0.003)\end{array}$ & $\begin{array}{c}-0.0212^{*} \\
(0.011)\end{array}$ & 0.0152 \\
\hline Gamma (fish) & $\begin{array}{c}0.0618^{*} \\
(0.013)\end{array}$ & $\begin{array}{c}-0.0122 \\
(0.011)\end{array}$ & $\begin{array}{c}-0.0236^{*} \\
(0.007)\end{array}$ & $\begin{array}{l}0.0037 \\
(0.003)\end{array}$ & $\begin{array}{l}-0.0145 \\
(0.009)\end{array}$ & -0.0153 \\
\hline Gamma (meat) & & $\begin{array}{c}0.1133^{*} \\
(0.018)\end{array}$ & $\begin{array}{c}-0.0325^{*} \\
(0.010)\end{array}$ & $\begin{array}{c}-0.0181 * \\
(0.004)\end{array}$ & $\begin{array}{c}-0.0387^{*} \\
(0.013)\end{array}$ & 0.0117 \\
\hline Gamma (milk ) & & & $\begin{array}{c}0.0739 * \\
(0.012)\end{array}$ & $\begin{array}{c}-0.0110^{*} \\
(0.005)\end{array}$ & $\begin{array}{l}-0.0054 \\
(0.010)\end{array}$ & -0.0014 \\
\hline Gamma (eggs) & & & & $\begin{array}{c}0.0240^{*} \\
(0.004)\end{array}$ & $\begin{array}{l}0.0031 \\
(0.005)\end{array}$ & -0.0017 \\
\hline Gamma (vegetables) & & & & & $\begin{array}{c}0.0553 * \\
(0.016)\end{array}$ & 0.0002 \\
\hline Gamma (fruits) & & & & & & 0.0299 \\
\hline Income Class 2 & $\begin{array}{l}-0.0133 \\
(0.019)\end{array}$ & $\begin{array}{l}-0.0023 \\
(0.021)\end{array}$ & $\begin{array}{l}0.0062 \\
(0.012)\end{array}$ & $\begin{array}{l}-0.0019 \\
(0.005)\end{array}$ & $\begin{array}{l}0.0047 \\
(0.016)\end{array}$ & 0.0066 \\
\hline Income Class 3 & $\begin{array}{l}-0.0133 \\
(0.019)\end{array}$ & $\begin{array}{c}-0.0114 \\
(0.022)\end{array}$ & $\begin{array}{l}0.0094 \\
(0.013)\end{array}$ & $\begin{array}{l}-0.0004 \\
(0.005)\end{array}$ & $\begin{array}{l}0.0072 \\
(0.017)\end{array}$ & 0.0085 \\
\hline Income Class 4 & $\begin{array}{l}-0.0099 \\
(0.021)\end{array}$ & $\begin{array}{c}-0.0667^{*} \\
(0.024)\end{array}$ & $\begin{array}{c}0.0356 * \\
(0.014)\end{array}$ & $\begin{array}{l}-0.0082 \\
(0.005)\end{array}$ & $\begin{array}{l}0.0058 \\
(0.019)\end{array}$ & 0.0434 \\
\hline Income Class 5 & $\begin{array}{c}-0.0781 * \\
(0.026)\end{array}$ & $\begin{array}{r}-0.0287 \\
(0.028)\end{array}$ & $\begin{array}{c}0.0303 * \\
(0.014)\end{array}$ & $\begin{array}{l}0.0054 \\
(0.007)\end{array}$ & $\begin{array}{l}0.0208 \\
(0.022)\end{array}$ & 0.0503 \\
\hline Family size & $\begin{array}{c}0.0217^{*} \\
(0.013)\end{array}$ & $\begin{array}{c}-0.0094 \\
(0.014)\end{array}$ & $\begin{array}{r}-0.0093 \\
(0.008)\end{array}$ & $\begin{array}{c}0.0082 * \\
(0.003)\end{array}$ & $\begin{array}{r}-0.0121 \\
(0.010)\end{array}$ & 0.0009 \\
\hline Large City & $\begin{array}{l}-0.0246 \\
(0.023)\end{array}$ & $\begin{array}{l}-0.0129 \\
(0.025)\end{array}$ & $\begin{array}{l}0.0184 \\
(0.015)\end{array}$ & $\begin{array}{c}-0.0105^{*} \\
(0.006)\end{array}$ & $\begin{array}{l}0.0419 * \\
(0.019)\end{array}$ & -0.0123 \\
\hline Medium Sized City & $\begin{array}{l}-0.0045 \\
(0.002)\end{array}$ & $\begin{array}{r}-0.0333 \\
(0.021)\end{array}$ & $\begin{array}{c}0.0176 \\
(0.012)\end{array}$ & $\begin{array}{r}-0.0067 \\
(0.005)\end{array}$ & $\begin{array}{c}0.0485^{*} \\
(0.015)\end{array}$ & -0.0216 \\
\hline Children under 6 & $\begin{array}{c}-0.0293 * \\
(0.015)\end{array}$ & $\begin{array}{l}-0.0045 \\
(0.016)\end{array}$ & $\begin{array}{l}0.0318 * \\
(0.010)\end{array}$ & $\begin{array}{l}-0.0041 \\
(0.004)\end{array}$ & $\begin{array}{l}0.0033 \\
(0.012)\end{array}$ & 0.0028 \\
\hline Children between 6-12 & $\begin{array}{c}-0.0149 \\
(0.014)\end{array}$ & $\begin{array}{r}-0.0025 \\
(0.015)\end{array}$ & $\begin{array}{l}0.0134 \\
(0.009)\end{array}$ & $\begin{array}{l}0.0003 \\
(0.004)\end{array}$ & $\begin{array}{l}0.0054 \\
(0.011)\end{array}$ & -0.0017 \\
\hline Children between 12-18 & $\begin{array}{r}-0.0245 \\
(0.019)\end{array}$ & $\begin{array}{c}0.0543 * \\
(0.022)\end{array}$ & $\begin{array}{l}0.0130 \\
(0.012)\end{array}$ & $\begin{array}{r}-0.0059 \\
(0.005)\end{array}$ & $\begin{array}{r}-0.0049 \\
(0.016)\end{array}$ & -0.0320 \\
\hline $\mathrm{R} 2$ & 0.168 & 0.169 & 0.196 & 0.316 & 0.145 & \\
\hline Adj. R2 & 0.129 & 0.131 & 0.159 & 0.284 & 0.106 & \\
\hline Sum Squared Residual & 3.105 & 3.765 & 1.351 & 0.214 & 2.165 & \\
\hline
\end{tabular}

${ }^{a}$ The figure in parenthesis is the standard error. Since the symmetry restriction is imposed, only upper triangular of these parameter estimates is reported.

* indicates statistically significant coefficient at $90 \%$ confidence. 
Appendix 2: Parameter estimates of the AIDS model for age group between 41 and $60^{\text {a }}$

\begin{tabular}{|c|c|c|c|c|c|c|}
\hline & Fish & Meat & Milk & Eggs & Vegetables & Fruits \\
\hline Alpha & $\begin{array}{c}-0.1699 * \\
(0.069)\end{array}$ & $\begin{array}{r}-0.0393 \\
(0.069)\end{array}$ & $\begin{array}{c}0.3936 * \\
(0.044)\end{array}$ & $\begin{array}{c}0.1903 * \\
(0.015)\end{array}$ & $\begin{array}{c}0.4869^{*} \\
(0.059)\end{array}$ & 0.1384 \\
\hline Beta & $\begin{array}{c}0.0511^{*} \\
(0.010)\end{array}$ & $\begin{array}{l}0.0137 \\
(0.010)\end{array}$ & $\begin{array}{c}-0.0323 * \\
(0.006)\end{array}$ & $\begin{array}{c}-0.0196^{*} \\
(0.002)\end{array}$ & $\begin{array}{c}-0.0189^{*} \\
(0.009)\end{array}$ & 0.0059 \\
\hline Gamma (fish) & $\begin{array}{c}0.0611^{*} \\
(0.012)\end{array}$ & $\begin{array}{c}-0.0295^{*} \\
(0.009)\end{array}$ & $\begin{array}{c}-0.0048 \\
(0.007)\end{array}$ & $\begin{array}{l}0.0034 \\
(0.003)\end{array}$ & $\begin{array}{c}-0.0098 \\
(0.008)\end{array}$ & -0.0203 \\
\hline Gamma (meat) & & $\begin{array}{c}0.1087^{*} \\
(0.013)\end{array}$ & $\begin{array}{c}-0.0261 * \\
(0.007)\end{array}$ & $\begin{array}{r}-0.0037 \\
(0.003)\end{array}$ & $\begin{array}{c}-0.0512^{*} \\
(0.009)\end{array}$ & 0.0018 \\
\hline Gamma (milk ) & & & $\begin{array}{c}0.0626^{*} \\
(0.008)\end{array}$ & $\begin{array}{r}-0.0069 \\
(0.003)\end{array}$ & $\begin{array}{c}-0.0171 * \\
(0.007)\end{array}$ & -0.0077 \\
\hline Gamma (eggs) & & & & $\begin{array}{c}0.0165^{*} \\
(0.002)\end{array}$ & $\begin{array}{c}-0.0037 \\
(0.003)\end{array}$ & -0.0055 \\
\hline Gamma (vegetables) & & & & & $\begin{array}{c}0.1098^{*} \\
(0.012)\end{array}$ & -0.0189 \\
\hline Gamma (fruits) & & & & & & -0.0506 \\
\hline Income Class 2 & $\begin{array}{c}0.0368 * \\
(0.018)\end{array}$ & $\begin{array}{l}0.0031 \\
(0.018)\end{array}$ & $\begin{array}{c}-0.0217^{*} \\
(0.011)\end{array}$ & $\begin{array}{l}0.0029 \\
(0.004)\end{array}$ & $\begin{array}{c}-0.0061 \\
(0.016)\end{array}$ & -0.0150 \\
\hline Income Class 3 & $\begin{array}{l}0.0134 \\
(0.016)\end{array}$ & $\begin{array}{l}0.0070 \\
(0.017)\end{array}$ & $\begin{array}{r}-0.0023 \\
(0.010)\end{array}$ & $\begin{array}{r}-0.0002 \\
(0.001)\end{array}$ & $\begin{array}{c}-0.0078 \\
(0.014)\end{array}$ & -0.0101 \\
\hline Income Class 4 & $\begin{array}{l}0.0178 \\
(0.016)\end{array}$ & $\begin{array}{c}-0.0178 \\
(0.016)\end{array}$ & $\begin{array}{l}0.0001 \\
(0.009)\end{array}$ & $\begin{array}{r}-0.0003 \\
(0.003)\end{array}$ & $\begin{array}{l}0.0119 \\
(0.013)\end{array}$ & -0.0117 \\
\hline Income Class 5 & $\begin{array}{l}0.0081 \\
(0.016)\end{array}$ & $\begin{array}{r}-0.0202 \\
(0.016)\end{array}$ & $\begin{array}{l}0.0117 \\
(0.010)\end{array}$ & $\begin{array}{r}-0.0017 \\
(0.003)\end{array}$ & $\begin{array}{l}0.0036 \\
(0.014)\end{array}$ & -0.0015 \\
\hline Family size & $\begin{array}{r}-0.0076 \\
(0.006)\end{array}$ & $\begin{array}{c}0.0101 * \\
(0.006)\end{array}$ & $\begin{array}{l}0.0046 \\
(0.003)\end{array}$ & $\begin{array}{c}0.0025^{*} \\
(0.001)\end{array}$ & $\begin{array}{r}-0.0017 \\
(0.005)\end{array}$ & -0.0079 \\
\hline Large City & $\begin{array}{c}-0.0208 \\
(0.015)\end{array}$ & $\begin{array}{l}0.0002 \\
(0.015)\end{array}$ & $\begin{array}{l}0.0031 \\
(0.009)\end{array}$ & $\begin{array}{c}-0.0053 \\
(0.003)\end{array}$ & $\begin{array}{l}0.0076 \\
(0.013)\end{array}$ & 0.0152 \\
\hline Medium Sized City & $\begin{array}{r}-0.0159 \\
(0.013)\end{array}$ & $\begin{array}{c}-0.0039 \\
(0.012)\end{array}$ & $\begin{array}{l}0.0107 \\
(0.007)\end{array}$ & $\begin{array}{c}-0.0038 \\
(0.002)\end{array}$ & $\begin{array}{r}-0.0017 \\
(0.011)\end{array}$ & -0.0146 \\
\hline Children under 6 & $\begin{array}{l}-0.0059 \\
(0.015)\end{array}$ & $\begin{array}{l}0.0111 \\
(0.014)\end{array}$ & $\begin{array}{c}-0.0006 \\
(0.009)\end{array}$ & $\begin{array}{c}-0.0028 \\
(0.003)\end{array}$ & $\begin{array}{l}0.0156 \\
(0.013)\end{array}$ & -0.0174 \\
\hline Children between 6-12 & $\begin{array}{c}-0.0228^{*} \\
(0.008)\end{array}$ & $\begin{array}{l}0.0111 \\
(0.008)\end{array}$ & $\begin{array}{c}0.0172 * \\
(0.005)\end{array}$ & $\begin{array}{l}0.0011 \\
(0.001)\end{array}$ & $\begin{array}{r}-0.0067 \\
(0.007)\end{array}$ & 0.0001 \\
\hline Children between 12-18 & $\begin{array}{c}-0.0194 * \\
(0.007)\end{array}$ & $\begin{array}{c}0.0343 * \\
(0.007)\end{array}$ & $\begin{array}{c}0.0075^{*} \\
(0.004)\end{array}$ & $\begin{array}{c}0.0029 * \\
(0.001)\end{array}$ & $\begin{array}{r}-0.0082 \\
(0.006)\end{array}$ & -0.0171 \\
\hline $\mathrm{R} 2$ & 0.164 & 0.195 & 0.188 & 0.281 & 0.143 & \\
\hline Adj. R2 & 0.145 & 0.176 & 0.169 & 0.264 & 0.123 & \\
\hline Sum Squared Residual & 7.188 & 7.071 & 2.681 & 0.282 & 5.185 & \\
\hline
\end{tabular}

${ }^{a}$ The figure in parenthesis is the standard error. Since the symmetry restriction is imposed, only upper triangular of these parameter estimates is reported.

* indicates statistically significant coefficient at $90 \%$ confidence. 
Appendix 3: Parameter estimates of the AIDS model for age group over than $60^{\text {a }}$

\begin{tabular}{|c|c|c|c|c|c|c|}
\hline & Fish & Meat & Milk & Eggs & Vegetables & Fruits \\
\hline Alpha & $\begin{array}{c}-0.2076 * \\
(0.104)\end{array}$ & $\begin{array}{c}0.2269^{*} \\
(0.088)\end{array}$ & $\begin{array}{c}0.5284 * \\
(0.065)\end{array}$ & $\begin{array}{c}0.1673 * \\
(0.018)\end{array}$ & $\begin{array}{c}0.2063 * \\
(0.092)\end{array}$ & 0.0787 \\
\hline Beta & $\begin{array}{c}0.0593^{*} \\
(0.014)\end{array}$ & $\begin{array}{c}-0.0294 * \\
(0.012)\end{array}$ & $\begin{array}{c}-0.0454^{*} \\
(0.008)\end{array}$ & $\begin{array}{c}-0.0180^{*} \\
(0.002)\end{array}$ & $\begin{array}{l}0.0051 \\
(0.013)\end{array}$ & 0.0284 \\
\hline Gamma (fish) & $\begin{array}{c}0.0796^{*} \\
(0.018)\end{array}$ & $\begin{array}{l}-0.0078 \\
(0.012)\end{array}$ & $\begin{array}{c}-0.0120 \\
(0.009)\end{array}$ & $\begin{array}{l}0.0037 \\
(0.003)\end{array}$ & $\begin{array}{c}-0.0327^{*} \\
(0.011)\end{array}$ & -0.0308 \\
\hline Gamma (meat) & & $\begin{array}{c}0.0669^{*} \\
(0.014)\end{array}$ & $\begin{array}{c}-0.0173 \\
(0.009)\end{array}$ & $\begin{array}{c}-0.0081^{*} \\
(0.003)\end{array}$ & $\begin{array}{c}-0.0054 \\
(0.011)\end{array}$ & -0.0284 \\
\hline Gamma (milk ) & & & $\begin{array}{c}0.0470 * \\
(0.011)\end{array}$ & $\begin{array}{c}-0.0056^{*} \\
(0.003)\end{array}$ & $\begin{array}{l}0.0003 \\
(0.008)\end{array}$ & -0.0124 \\
\hline Gamma (eggs) & & & & $\begin{array}{c}0.0157^{*} \\
(0.002)\end{array}$ & $\begin{array}{c}-0.0024 \\
(0.003)\end{array}$ & -0.0033 \\
\hline Gamma (vegetables) & & & & & $\begin{array}{c}0.0467^{*} \\
(0.015)\end{array}$ & -0.0064 \\
\hline Gamma (fruits) & & & & & & -0.0813 \\
\hline Income Class 2 & $\begin{array}{l}-0.0218 \\
(0.017)\end{array}$ & $\begin{array}{l}-0.0034 \\
(0.014)\end{array}$ & $\begin{array}{c}0.0049 \\
(0.010)\end{array}$ & $\begin{array}{l}-0.0017 \\
(0.003)\end{array}$ & $\begin{array}{c}-0.0163 \\
(0.015)\end{array}$ & 0.0383 \\
\hline Income Class 3 & $\begin{array}{r}-0.0241 \\
(0.019)\end{array}$ & $\begin{array}{r}-0.0049 \\
(0.017)\end{array}$ & $\begin{array}{c}0.0248^{*} \\
(0.012)\end{array}$ & $\begin{array}{r}-0.0013 \\
(0.003)\end{array}$ & $\begin{array}{c}-0.0173 \\
(0.017)\end{array}$ & 0.0228 \\
\hline Income Class 4 & $\begin{array}{c}-0.0139 \\
(0.024)\end{array}$ & $\begin{array}{l}0.0073 \\
(0.021)\end{array}$ & $\begin{array}{l}0.0207 \\
(0.014)\end{array}$ & $\begin{array}{c}-0.0018 \\
(0.004)\end{array}$ & $\begin{array}{c}-0.0267 \\
(0.021)\end{array}$ & 0.0144 \\
\hline Income Class 5 & $\begin{array}{r}-0.0075 \\
(0.023)\end{array}$ & $\begin{array}{r}-0.0065 \\
(0.020)\end{array}$ & $\begin{array}{c}0.0292 * \\
(0.014)\end{array}$ & $\begin{array}{l}0.0015 \\
(0.004)\end{array}$ & $\begin{array}{c}-0.0291 \\
(0.021)\end{array}$ & 0.0124 \\
\hline Family size & $\begin{array}{c}-0.0186^{*} \\
(0.011)\end{array}$ & $\begin{array}{l}0.0392 * \\
(0.009)\end{array}$ & $\begin{array}{l}-0.0061 \\
(0.006)\end{array}$ & $\begin{array}{l}0.0056 * \\
(0.002)\end{array}$ & $\begin{array}{l}0.0070 \\
(0.009)\end{array}$ & -0.0271 \\
\hline Large City & $\begin{array}{c}-0.0585^{*} \\
(0.024)\end{array}$ & $\begin{array}{c}-0.0402 * \\
(0.020)\end{array}$ & $\begin{array}{c}-0.0148 \\
(0.014)\end{array}$ & $\begin{array}{l}0.0028 \\
(0.003)\end{array}$ & $\begin{array}{c}0.0797 * \\
(0.021)\end{array}$ & 0.031 \\
\hline Medium Sized City & $\begin{array}{c}-0.0304 * \\
(0.019)\end{array}$ & $\begin{array}{l}-0.0209 \\
(0.017)\end{array}$ & $\begin{array}{c}-0.0213^{*} \\
(0.012)\end{array}$ & $\begin{array}{l}-0.0027 \\
(0.003)\end{array}$ & $\begin{array}{c}0.0757 * \\
(0.017)\end{array}$ & -0.0004 \\
\hline Children under 6 & $\begin{array}{l}0.0068 \\
(0.045)\end{array}$ & $\begin{array}{c}-0.0634 * \\
(0.038)\end{array}$ & $\begin{array}{c}0.0444 * \\
(0.026)\end{array}$ & $\begin{array}{c}-0.0089 \\
(0.007)\end{array}$ & $\begin{array}{r}-0.0043 \\
(0.039)\end{array}$ & 0.0254 \\
\hline Children between 6-12 & $\begin{array}{c}-0.0084 \\
(0.035)\end{array}$ & $\begin{array}{c}-0.0698^{*} \\
(0.030)\end{array}$ & $\begin{array}{c}0.0358^{*} \\
(0.021)\end{array}$ & $\begin{array}{c}-0.0113^{*} \\
(0.006)\end{array}$ & $\begin{array}{l}0.0016 \\
(0.031)\end{array}$ & 0.0521 \\
\hline Children between 12-18 & $\begin{array}{c}-0.0120 \\
(0.040)\end{array}$ & $\begin{array}{c}0.0679 * \\
(0.034)\end{array}$ & $\begin{array}{c}-0.0013 \\
(0.023)\end{array}$ & $\begin{array}{c}-0.0003 \\
(0.006)\end{array}$ & $\begin{array}{r}-0.0111 \\
(0.035)\end{array}$ & -0.0432 \\
\hline $\mathrm{R} 2$ & 0.192 & 0.174 & 0.201 & 0.304 & 0.103 & \\
\hline Adj. R2 & 0.158 & 0.139 & 0.167 & 0.274 & 0.065 & \\
\hline Sum Squared Residual & 4.881 & 3.528 & 1.688 & 0.127 & 3.743 & \\
\hline
\end{tabular}

${ }^{a}$ The figure in parenthesis is the standard error. Since the symmetry restriction is imposed, only upper triangular of these parameter estimates is reported.

* indicates statistically significant coefficient at $90 \%$ confidence. 